\title{
Assessment of age bias in site index equations
}

\author{
Jaroslaw Socha ${ }^{(1-2)}$, \\ Nicholas C Coops (2), \\ Wojciech Ochal ${ }^{(1)}$
}

\begin{abstract}
The most widely accepted method of evaluating site productivity is site index. In spite of some important restrictions it is still a useful concept in both forest research and management. One of the most important challenges when using site index is an age trend manifested by a negative correlation between site index and stand age. Age trend may result from the inappropriateness of site index models. In this paper we develop a new approach for assessing age bias in site index models. Field data collected from 311 sample plots established in Norway spruce stands in the Polish region of the Carpathians formed the basis of this study. In the proposed approach the appropriateness of site index models is assessed by analyzing the existence of age trends in residuals of geocentric site index prediction models. Using the developed approach we demonstrated that when significant correlations exist between residuals of site index prediction models and stand age, it likely indicates the existence of an age trend and thus the inappropriateness of site index model. To remedy this situation, we demonstrated that the observed age trend can be quantified and utilized in new, non-biased, site index models.
\end{abstract}

Keywords: Site Productivity, Age Trend, Climate Change, Height Growth, Site Index Model

\section{Introduction}

Site productivity is a quantitative estimate of the potential of a site to produce plant biomass (Skovsgaard \& Vanclay 2008). Forest site productivity remains a fundamental variable in forestry (Bontemps \& Bouriaud 2013). Reliable estimates of potential site productivity are essential for sustainable forest management, as it is often a key criteria when considering siteand species-specific decisions concerning species composition, silvicultural treatments, determining allowable cut, rotation period and forecast of timber yield (Splechtna 2001, Pretzsch et al. 2008). To be most useful for modeling and prediction, a measure of site quality must be quantitative, that is expressed by a number (Burkhart $\&$ Tomé 2012).

The most commonly used and widely accepted method of evaluating site productivity is site index (Skovsgaard \& Vanclay 2008, Sharma et al. 2011). In spite of the fact that in many cases site index is not

always sufficient to characterize site productivity (Bontemps \& Bouriaud 2013), it is still one of the most widely used indicators of wood production and is useful in both forest research and management (Skovsgaard \& Vanclay 2013). Therefore, the construction of site index models remains a fundamental task for site productivity differentiation (Skovsgaard \& Vanclay 2008, 2013, Sharma et al. 2011).

One of the most important challenges in the site index concept is an age trend manifested by a negative correlation between site index and stand age, which has been frequently reported (Elfving \& Tegnhammar 1996, Socha 2008, Albert \& Schmidt 2010, Nothdurft et al. 2012, Sharma et al. 2012, Yue et al. 2014). In most studies problems associated with age trend in site index resulted from changes in site conditions caused by non-static factors: nitrogen deposition, increasing $\mathrm{CO}_{2}$ concentration and climate change (Elfving \& Tegnhammar 1996, Hasenauer et al. 1999, Schadauer
(1) Department of Biometry and Forest Productivity, Faculty of Forestry, University of Agriculture in Krakow, Al. 29-listopada 46, 31-425 Krakow (Poland); (2) Integrated Remote Sensing Studio, Department of Forest Resources Management, Faculty of Forestry, University of British Columbia, 2424 Main Mall, BC V6T 1Z4, Vancouver (Canada)

@ Jaroslaw Socha (rlsocha@cyf-kr.edu.pl)

Received: Dec 30, 2014 - Accepted: Dec 10, 2015

Citation: Socha J, Coops NC, Ochal W (2016). Assessment of age bias in site index equations. iForest 9: 402-408. - doi: 10.3832/ifor1548-008 [online 2016-01-11]

Communicated by: Agostino Ferrara
1999, Fries et al. 2000, Solberg et al. 2009, Nothdurft et al. 2012, Sharma et al. 2012, Bontemps \& Bouriaud 2013, Yue et al. 2014). Highly productive forests are usually managed under short rotation, and consequently older stands may be over-represented on infertile sites, since they require a longer time to reach a certain goal of wood production which also can cause an age trend in site index estimates (Tegnhammar 1992, Nothdurft et al. 2012, Yue et al. 2014).

In a study conducted in Sweden, Johansson (1995) found significant variation in site index curves of forest stands due to mineral soil type and geographical location. Effect of genetic variability on the height development of trees and resulting age trends were also reported by Adams et al. (2006). Genetic variability has been identified as the factor modifying the trajectory of site index curves by Buford \& Burkhart (1987), who found that the site index curves developed for different provenances differed in their parameters describing the asymptote for height growth. Climate, soil and genotype-by-environmental interactions can favor the adaptation of species to local ecological conditions, causing variable height patterns for the same species among ecoregions (Monserud \& Rehfeldt 1990, Alvarez-González et al. 2005). Significant differences in the pattern of tree heights can also occur for the same species, even within a given site index class (Monserud 1984). García (2010) reported that three sources of height growth development variability can be identified: (a) between sites, (b) within sites, and (c) observation error. The differences between 
site index model trajectories with age may also result both from the method and data used in deriving site equations (Cieszewski 2001, Cieszewski \& Strub 2007).

In order to avoid age bias in site index prediction, Sharma et al. (2012) included age as one of the predictor variables in site index prediction models for Norway spruce in Norway and obtained an increase in the proportion of explained variance. Including age as one of the variables reduces bias of site index prediction model; however, in such cases the problem with age trend in the site index model still remains unsolved. A different approach was used by Bøhler \& Bernt-Håvar (2011), which proposed a linear correction of site index models in order to take into account the inappropriacy of site index model for Norway spruce resulting from age trend in high altitude semi-natural old stands in Norway.

In summary, an accurate site index model should take into consideration age trends irrespectively of its source, and ignoring these potential biases will cause erroneous assessment of site productivity. Therefore, there is a need to have a practical procedure which allows managers to assess if particular site index models are sufficiently reliable for describing the site productivity of given tree species in areas of interest. In the case of a lack of adequate models, it follows there is a further need to develop more appropriate models by fitting baseage invariant dominant height equation. The decision as to whether existing site index models are sufficiently accurate or whether new site-specific site index models are required for local site conditions should be based on consistent and well developed criteria. However, in the forestry literature the aspect of adequacy of site index models which is very important both from the practical and scientific view point has rarely been analysed. In most cases authors suggested inappropriateness of site index models based on simple comparisons of site index curves obtained from stem analysis or permanent sample plots with site index models or tables. These comparisons assume that the collected tree or plot observations data effectively describes changes in stand height with age. However, the appropriateness of such assumptions is not valid in many cases and just because the measured and modeled height does not match, it does not mean the site index equation is bad.

In this paper we develop a new approach for the assessment of site index models. In the proposed approach the appropriateness of site index models is assessed by analyzing the existence of age trends in residuals developed using forest inventory data and environmental characteristics. According to the developed procedure, a significant correlation between residuals of site index prediction models and stand age indicates the existence of a bias resulting from an age trend and thus the inappropriateness of site index model. We used resi- dual values of site index prediction models instead of a direct correlation of site index models with age in order to remove frequently observed effects of over-representation of older stands on infertile sites or other types of unequal distribution of sample plots in given ages on different environmental gradients. In cases where site index models have a demonstrated age trend we proposed a correction procedure which takes into consideration the age trend found during the validation process by incorporating it into the new site index model.

\section{Material and methods}

\section{A case study area and sample design}

Norway spruce stands in the Polish part of Western Carpathians ( $18^{\circ} 48^{\prime} 50^{\prime \prime} \mathrm{E}$ and $19^{\circ} 58^{\prime} 58^{\prime \prime} \mathrm{E}$ longitude, $49^{\circ} 23^{\prime} 52^{\prime \prime} \mathrm{N}$ and $49^{\circ} 41^{\prime} 3^{\prime \prime} \mathrm{N}$ latitude) formed the basis of this study. Field data were collected from 311 sample plots located in even-aged spruce stands aged 40-157 years. The stands were located between 540-1360 m a.s.l. Sample plots were located in a regular $(1250 \times 1250 \mathrm{~m})$ grid and were circular ranging in size from 0.02-0.10 ha. The lowest number of trees per plot was 8 and the maximum 62, with an average of 27. Tree height and diameter at breast height were measured for all trees in the sample plots.

Top height of individual plots was calculated from the mean height of the 100 largest trees per hectare. The age of each plot was determined from at least six dominant trees by counting the number of rings on increment cores extracted using an increment borer at a height of between $20-30 \mathrm{~cm}$ above the ground surface, adding 3 years to reach the point of extraction. In general, the difference in age among individual trees in the sample plots was less than 3-5 years.

At each plot the characteristics of topography and the geological substratum were also assessed. Topography was described by the elevation above the sea level $(E)$ measured with the use of an altimeter, the aspect $(A)$ measured in degrees with a compass, the slope $(S)$ and the landform category (LC). Landform category was derived from a $10 \times 10 \mathrm{~m}$ digital terrain model using a combination of topographic position indexes for the scale of 300 and 2000 meters. Geological substratum (Gs) was estimated for individual plots using the geological map in the scale of 1:50 000. For the modeling purpose, the aspect values were transformed as follows (eqn. 1):

$$
K_{B}=\sin \left(A+\left(90-A_{\max }\right)\right)+1
$$

where $K_{\mathrm{B}}$ is the transformed value of aspect, varying from 0 to $2, A$ is the aspect expressed by azimuth (degrees), $A_{\max }$ is the assigned direction (azimuth) of maximum importance, the value $A_{\max }=45^{\circ}$ was assumed.

In the analysis the relationships between the site index and predictor variables were investigated using generalized additive models (GAM, Hastie \& Tibshirani 1990 - eqn. 2).

$$
\begin{gathered}
G(E(Y))=\beta+f_{1} X_{1}+f_{2} X_{2}+f_{3} X_{3}+ \\
f_{n} X_{n}+\varepsilon
\end{gathered}
$$

where $Y$ is the dependent variable, $X_{\mathrm{i}}$ are the predictor variables, $G$ is the link function, $f_{1}, f_{2}, \ldots, f_{\mathrm{n}}$ are smoothing spline functions estimated from the data, $\beta$ is a free term, and the errors $\varepsilon$ are assumed to have constant variance and mean of $o$.

GAM's were selected as the tool for analysis because they are ranked as one of the most sufficient modeling techniques for the development of site index prediction models (Aertsen et al. 2010). The relationship between residuals of GAM models and age of the stands was analyzed using standard linear models.

\section{The procedure of validation of site index models}

The proposed method of validation and correction of site index models was applied to three site index models used in practice for Norway spruce in Poland.

(1) An anamorphic site index model for Norway spruce in Poland $\left(S I_{B}\right)$ developed by Bruchwald et al. (1999) using the stem analysis data collected from 548 Norway spruce stands located at the lowland area of North-eastern and mountain area of southern Poland (eqn. 3):

$$
S I_{B}=\frac{H}{A_{T}}
$$

where $S I_{B}$ denotes the site index with a base age of 100 years, $H$ is the top height of the stand, and $A_{\mathrm{T}}$ is an age-dependent function defined as (eqn. 4):

$$
A_{T}=\left(\frac{T}{7+0.25 \cdot T}\right)^{2.5} \cdot \frac{1}{17.26334915}
$$

where $T$ denotes the age of the stand in years.

(2) The site index model describing Lorey mean height growth trajectories from Schwappach (1943) yield tables $\left(S I_{\mathrm{S}}\right)$ developed with the use of base age specified method (eqn. 5):

$$
S I_{S}=H_{L} \cdot\left(\frac{1-e^{-0.0161497 \cdot 100}}{1-e^{-0.0161497 \cdot T}}\right)^{17.2564 H_{L}^{-0.714128}}
$$

where $H_{\mathrm{L}}$ is the Lorey mean height at the age $T$.

(3) The site index model for Norway spruce in Polish Mountains $\left(S I_{\mathrm{M}}\right)$ developed using the GADA method based on height growth trajectories obtained from stem analysis of 162 individual trees measured from 53 sample plots located in the Polish Carpathians (Socha 2011 - eqn. 6):

$$
S I_{M}=H \frac{100^{1.95817}\left(T^{1.95817} R+66568.71\right)}{T^{1.95817}\left(100^{1.95817} R+66568.71\right)}
$$

where $H$ is the top height at the age $T$ and $R$ is defined as (eqn. 7): 


$$
\begin{aligned}
& R=-15.03036+H+ \\
& {\left[(-15.03036+H)^{2}+\frac{2 H \cdot 66568.71}{T^{1.95817}}\right]^{0.5}}
\end{aligned}
$$

The proposed validation procedure of the site index models described above is outlined as follows. Initially, each site index model was used for the calculation of site index values for all of the sample plots. Two approaches were then developed to assess the adequacy and validity of these site index estimates.

First, the relationship between the site index calculated on the basis of eqn. 3, eqn. 5 or eqn. 6 and the available environmental variables is modeled using the developed GAM. The result of this analysis is a site index prediction model describing the site index as a function of a number $n$ of site characteristics $X_{\mathrm{n}}$ (eqn. 2). The adequacy of site index models to the local conditions is validated based on the relationship between the residuals from the model fitted in step 2, and stand age. The existence of a significant correlation between the residuals from the site index prediction model and stand age implies that there are systematic errors in the site index determination.

Secondly, we demonstrated an alternative approach using the age of the stands as one of the independent variables in the site index prediction model (SIPM). In this case the significance of "age" as an independent variable in SIPM demonstrates the inadequacy of site index model. As a result, the height of stands in base ages will be under- or overestimated. The "+" sign of the parameter connected with the variable "age" in SIPM model indicates that site index for young stands is underestimated and overestimated for older stands. In the opposite case a "-" implies overestimation of site index for young and overestimation for old stands.

Procedure of temporary adjusting of site index model to local site conditions by incorporating age trend

Assuming that a site index model is proven invalid, we proposed a simple proce- dure to adjust the model to the local growth conditions. Using the regression model describing the relationship between residuals of the site index prediction model and the stand age, it is possible to determine the error in the predicted site index as a function of stand age. The relationship between the residuals of the site index prediction model and the stand age can be described both using a simple linear regression model (eqn. 8):

$$
\delta_{S I P M}=\beta_{0} \cdot(T-100)+\varepsilon
$$

where $\delta_{\text {SIPM }}$ is the error of site index prediction model, $\beta_{0}$ is the model parameter, $T$ denotes the stand age and $\varepsilon$ the random residual error of the equation.

The site index of the stand at a given age is then corrected by subtracting the correction factor calculated as the difference between the calculated $S I$ and the error described by eqn. 9, which subsequently removes the age trend from site index model (eqn. 9):

$$
S I_{c o r}=S I-\delta_{S I P M}
$$

where $S I_{\text {cor }}$ denotes the corrected value of site index, $S I$ denotes the value of the site index calculated on the basis of the validated model, and $\delta_{\text {SIPM }}$ denotes the error of the site index prediction model calculated from eqn. 8.

The above procedure allows systematic errors from inadequate models due to age trend to be minimized. It should be noted, however, that the eliminated systematic errors are also free from the influence of unbalanced distribution of sample plots across different site conditions. Using the proposed approach, it is also possible to adjust invalid site index models using a correction factor $I_{\text {cor }}$, defined as (eqn. 10):

$$
I_{c o r}=\left(I \cdot \frac{S I_{E}}{S I_{c o r}}\right)
$$

where $S I_{\mathrm{E}}$ denotes the observed (existing) value of site index, and (eqn. 11):

$$
I=\frac{H_{T}}{H_{B A}}
$$

where $H_{\mathrm{T}}$ is the height of the stand at specified age $T$, and $H_{\mathrm{BA}}$ is the height of the stand in a base age.

Corrected value of the stand height trajectory $\left(H_{\text {cor }}\right)$ in a certain age is calculated by its multiplication by the correction factor $\left(I_{\text {cor }}\right)$ according to the following equation (eqn. 12):

$$
H_{c o r}=I_{c o r} \cdot S I_{E}
$$

\section{Results}

\section{Validation of Bruchwald's site index} model $\left(\mathrm{SI}_{B}\right)$

First, a local site index GAM model describing $S I_{B}$ as a function of site characteristics was developed. It was found that the site index calculated using the Bruchwald et al. (1999) model was significantly correlated with site characteristics including altitude, product of slope and elevation ( $\mathrm{S} \times$ $K_{B}$ ), geological layer and landform category (Tab. 1), and explains $71.8 \%$ of the variability of site index $\left(S I_{\mathrm{B}}\right)$. Residuals from this site index prediction model were significantly correlated with the stand age $(T)$, which explain over $34 \%$ of the variability (Fig. 1 , Tab. 2). This relationship was described by linear regression model (eqn. 13):

$$
\delta_{S I_{B}}=-0.06561 \cdot(T-100)
$$

where $\delta_{\mathrm{SIB}}$ denotes the error of site index estimation using the site index prediction model, and $T$ the age of the stand.

Using the second approach that included "age" into site index prediction model, the proportion of explained variance significantly increased to $81.6 \%$ (Tab. 2).

Applying our approach, the observed significant correlation between residuals of the site index prediction model and the stand age, as well as the significance of the age variable in the SIPM age trend, implied

\begin{tabular}{|c|c|c|}
\hline $\begin{array}{l}\text { Dependent variable - } \\
\text { site index model } \\
\text { (model source) }\end{array}$ & $\begin{array}{l}\text { Predictor } \\
\text { variables }\end{array}$ & $\begin{array}{l}\text { Adjusted } \\
R^{2}\end{array}$ \\
\hline $\begin{array}{l}S I_{B} \\
\text { (Bruchwald et al. 1999) }\end{array}$ & $\begin{array}{l}\text { elevation above sea level }(E) \text {, product of slope and aspect }\left(S \times K_{\mathrm{B}}\right) \text {, landform } \\
\text { category }(L c) \text {, geological substratum }(G s)\end{array}$ & 71.8 \\
\hline $\begin{array}{l}S I_{B} \\
\text { (Bruchwald et al. 1999) }\end{array}$ & $\begin{array}{l}\text { elevation above sea level }(E) \text {, product of slope and aspect }\left(S \times K_{\mathrm{B}}\right) \text {, landform } \\
\text { category }(L c) \text {, geological substratum }(G s) \text {, stand age }(T)\end{array}$ & 81.6 \\
\hline $\begin{array}{l}\text { S/s } \\
\text { (Schwappach 1943) }\end{array}$ & $\begin{array}{l}\text { elevation above sea level }(E) \text {, product of slope and aspect }\left(S \times K_{\mathrm{B}}\right) \text {, landform } \\
\text { category }(L c) \text {, geological substratum }(G s)\end{array}$ & 80.4 \\
\hline $\begin{array}{l}\text { SIs } \\
\text { (Schwappach 1943) }\end{array}$ & $\begin{array}{l}\text { elevation above sea level }(E) \text {, product of slope and aspect }\left(S \times K_{\mathrm{B}}\right) \text {, landform } \\
\text { category }(L c) \text {, geological substratum }(G s) \text {, stand age }(T)\end{array}$ & 81.6 \\
\hline (Socha 2011) & $\begin{array}{l}\text { elevation above sea level }(E) \text {, product of slope and aspect }\left(S \times K_{\mathrm{B}}\right) \text {, landform } \\
\text { category }(L c) \text {, geological substratum }(G s)\end{array}$ & 81.2 \\
\hline $\begin{array}{l}S I_{M} \\
\text { (Socha 2011) }\end{array}$ & $\begin{array}{l}\text { elevation above sea level }(E) \text {, product of slope and aspect }\left(S \times K_{\mathrm{B}}\right) \text {, landform } \\
\text { category }(L c) \text {, geological substratum }(G s) \text {, stand age }(T)\end{array}$ & 81.5 \\
\hline
\end{tabular}
an age trend bias and indicated the inadequacy of the $S I_{B}$ model under local site conditions. This inadequacy results in systematic errors in site index estimation.

Tab. 1 - Site index prediction models describing the relationship between site indexes calculated using the assessed site index models used for Norway spruce in Poland $\left(S I_{B}, S I_{S}\right.$ and $\left.S I_{M}\right)$ and selected predictor variables developed using generalized additive models techniques. 
Tab. 2 - Characteristics of the models describing the relationship between residuals of site index prediction models and the age of stands (eqn. 7).

\begin{tabular}{lccr}
\hline $\begin{array}{l}\text { Site index } \\
\text { model }\end{array}$ & $\begin{array}{c}\text { Value of } \\
\text { parameter }\end{array}$ & $R^{2}$ & $p$-level \\
\hline$S I_{B}$ & -0.06551 & 0.34 & $<0.00001$ \\
$S I_{S}$ & -0.01116 & 0.17 & 0.00029 \\
$S I_{M}$ & 0.00212 & 0.01 & 0.89331 \\
\hline
\end{tabular}

Fig. 1 - Relationship between residual values (obs-pred) of the site index prediction model based on validated site index model $\mathrm{SI}_{\mathrm{B}}$ (Bruchwald et al. 1999) and the age of stands.

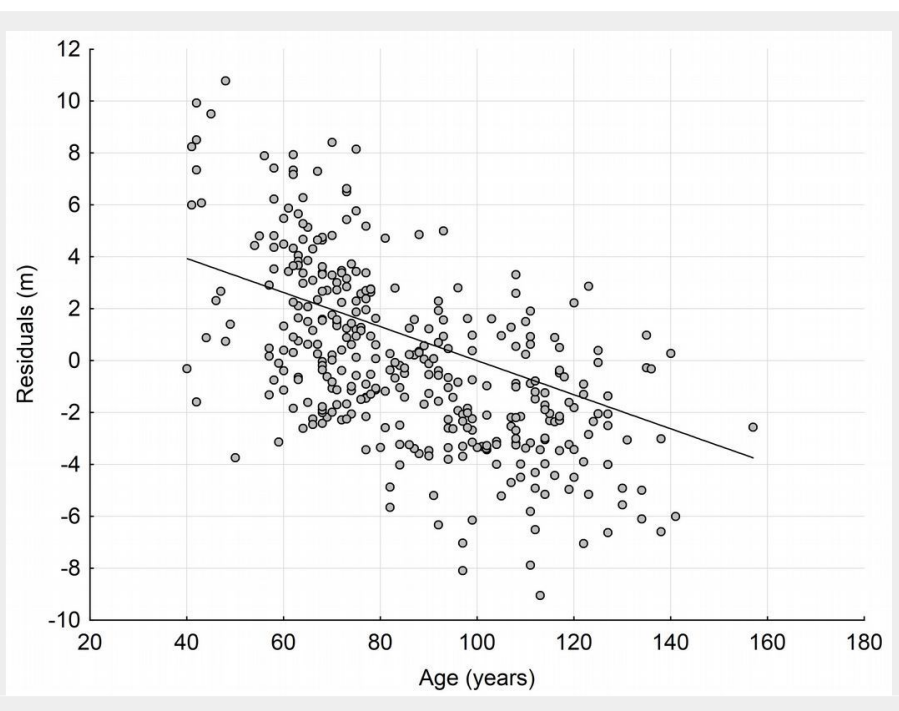

Fig. 2 - Relationship between residual values (obs-pred) of site index prediction model developed for site indexes calculated on the basis of Schwappach (1943) site index model $\mathrm{SI}_{\mathrm{s}}$ and age of the stands.

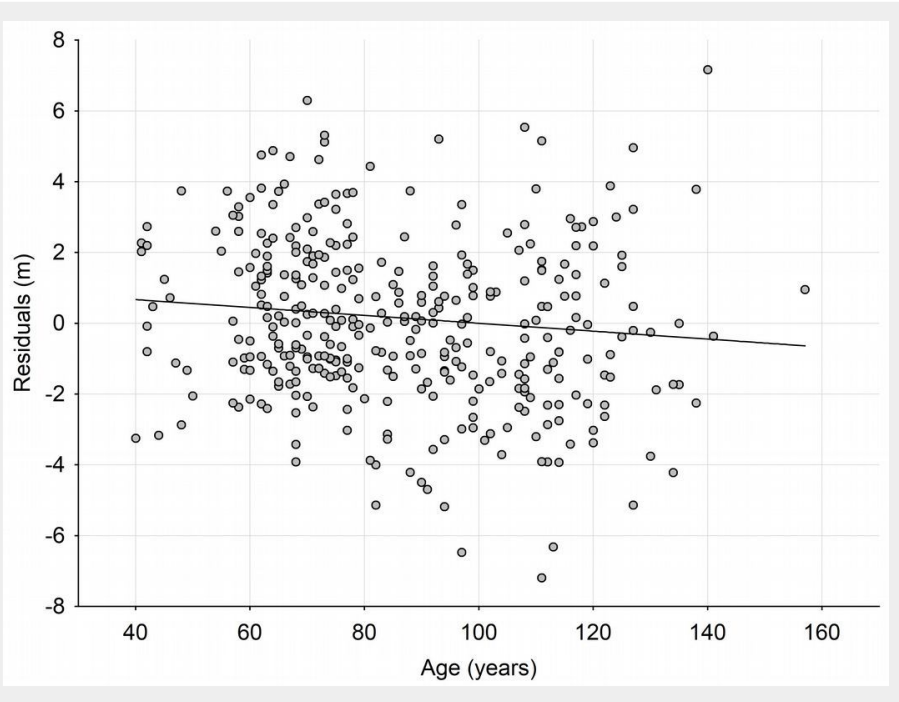

Fig. 3 - Relationship between residual values (obs-pred) of site index prediction model based on local site index model

$S I_{M}$ for Polish mountain

(Socha 2011) and stand ages.

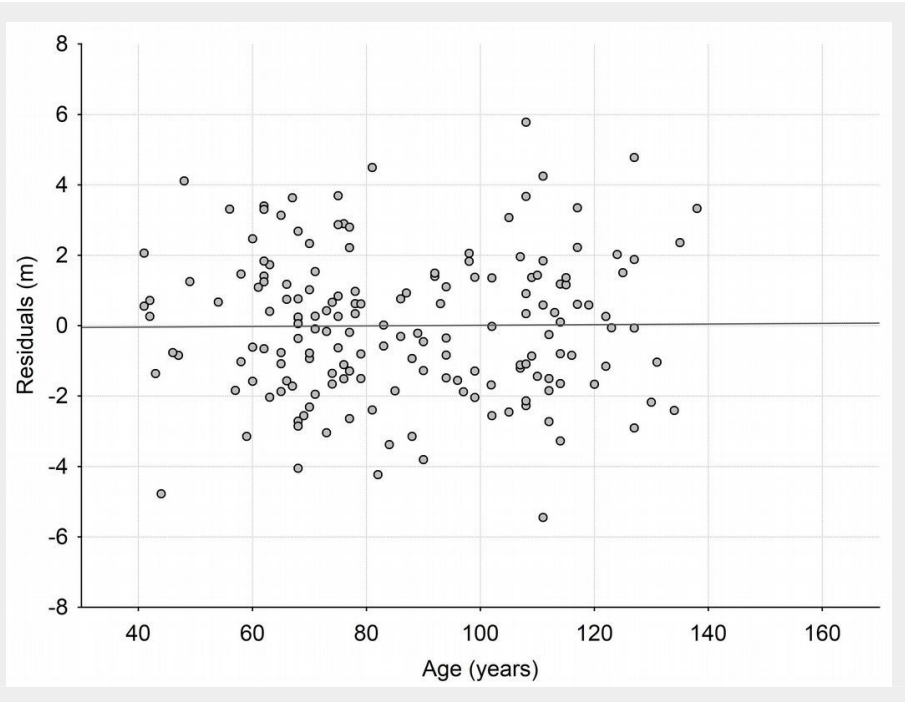

Validation of site index model by Schwappach $\left(\mathrm{SI}_{S}\right)$

Site indexes $S I_{\mathrm{S}}$ were calculated using the site index model by Schwappach (1943) and used as dependent variables in a GAM site index prediction model. In this case, the variance explained by the model $(80.4 \%$ - Tab. 1 ) is substantially higher than the variance of the site index prediction model developed using $S I_{\mathrm{B}}$ as the dependent variable. By including the variable "age" in this site index prediction model, the variance only slightly increases to $81.6 \%$. Also, stand age was a significant variable when added to the SIMP equation. However, residuals of the site index prediction model are weakly correlated with the stand age $(T)$ explaining only about $17 \%$ the total variation (Fig. 2, Tab. 2).

Validation of the site index model for Norway spruce of Polish mountains $\left(S I_{M}\right)$

Lastly, the site index prediction GAM model for $S I_{\mathrm{M}}$ (eqn. 5) as function of environmental factors was fitted (Tab. 1). Again, the validation of the $S I_{\mathrm{M}}$ model was based on the analysis of the relationship between residuals of the site index prediction GAM model (Tab. 1) and stand age. In this case, no significant correlation was detected between the residuals of site index prediction model developed with the use of $S I_{M}$ and stand age (Fig. 3, Tab. 2).

Considering stand age in site index prediction model with $S I_{\mathrm{M}}$ as the independent variable also showed no increase in the explained variance. As a result, in this case, there was no systematic error in site index estimation related to age of the stands (Fig. 3, Tab. 2), thus the site index is stable along the stand age.

The example of temporary correction of $S I_{B}$ model to local conditions

The results of the analysis indicated a strong age trend in site index resulting from the use of the $S I_{\mathrm{B}}$ model in local conditions. Therefore, the proposed correction procedure equation describing the dependence of expressed residuals of SIPM on stand age was used to adjust the height development patterns of the $S I_{B}$ model. Examples of the correction are graphically presented for individual SI curves 20m, $25 \mathrm{~m}, 30 \mathrm{~m}, 35 \mathrm{~m}$ in Fig. 4. In general, in the case of medium and good sites showing a site index over $25 \mathrm{~m}$, there is close similarity between the corrected $S I_{\mathrm{B}}$ and the local $S I_{\mathrm{M}}$ site index models (Fig. 4). Only the least productive stands had large differences (Fig. 4).

Height increment analysis indicates that, in the case of SI model developed for local conditions of Polish mountains for stands up to 45 years old, the height growth rate is higher than that assumed in the model $S I_{B}$, whereas for stands over 50 years the height growth rate is lower than expected by the validated model. Especially, large differences in site index curves are obser- 
ved for the oldest stands ( $>100$ years - Fig. 4). The above mentioned differences are the reason of the overestimation of site index for younger stands and underestimation of site index for stands in ages older than base age (100 years).

\section{Discussion}

Inappropriateness of site index models manifested by age trend has been widely observed (Spiecker et al. 1996, Subedi et al. 2009, Bøhler \& Bernt-Håvar 2011, Socha \& Orzel 2011). The existence of correlations between site index and stand age have been frequently reported and most often an age trend has been interpreted as driven by changes in site conditions (Elfving \& Tegnhammar 1996, Kiviste 1999, Bravo-Oviedo et al. 2010, Nothdurft et al. 2012, Yue et al. 2014). However, other important sources of site index model inappropriateness are reported, such as local differences in top height trajectories resulting from specific site conditions (Johansson 1995), genetic variability (Buford \& Burkhart 1987 , Adams et al. 2006) and inappropriate data, model or methods used in development of site index model (Cieszewski 2001, Cieszewski \& Strub 2007, García 2010).

Site index estimated on the basis of stand height and age is only an approximation of an unobservable site variable, which express the site conditions for given tree species. As a consequence of the aforementioned definition, it can be assumed that:

- Environmental drivers and the associated plant physiological response remain constant over the life of the stand, without changes in genetic structure, forest management practices or any other modifying growth factors. Given the same site conditions, site index values calculated for young stands should be equal to site index of older stands. Therefore, in such cases the site index curves describing change in height with age for young and old stands should be similar.

- In the case of deteriorated or improved site conditions (such as those caused by improved climatic conditions, $\mathrm{CO}_{2}$ fertilization or nitrogen deposition, genetic improvement, change in forest management practices or other factors influencing growth rate), younger stands may grow faster and therefore trajectories describing change in stand height with age for younger stands are different from those for older stands (Nothdurft et al. 2012, Yue et al. 2014). As the consequence of the change in site productivity over time, models describing change in stand height with age are not explicitly linked to site index. In such cases site index models should take into account time trend in site productivity in order to obtain comparable site indexes for sites characterized with comparable site productivity, irrespectively of the age of stand growing in a given location. Otherwise, the use of site index is restricted only to stands in a specific age range.

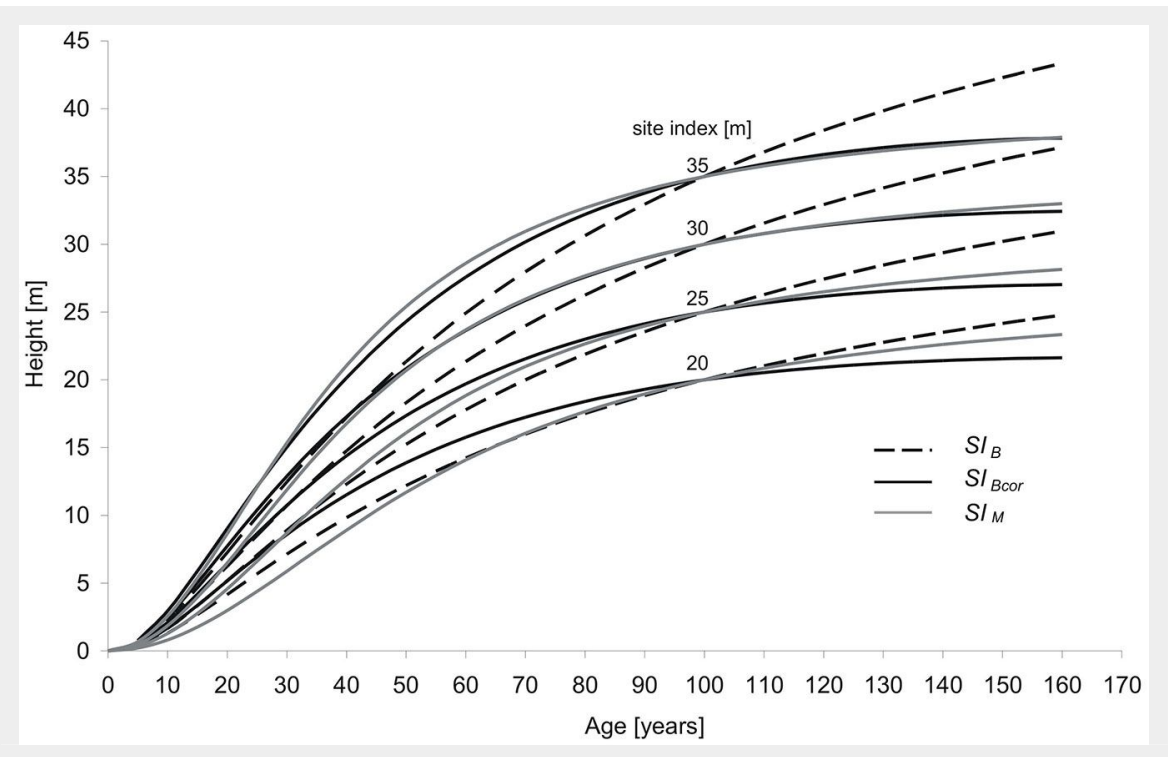

Fig. 4 - Actual $\left(S I_{B}\right.$ - dotted line) and corrected ( $S I_{B c o r}$ - solid line) site index curves drawn on the basis of the $S I_{B}$ model by Bruchwald et al. (1999) against a background of site index curves drawn with the use of local site index model $S I_{M}$ (grey line) for Polish mountains (Socha 2011).

The proposed procedure assumes that the residuals from the SIPM describing the site index as the function of site properties should not be correlated with stand age. Site index prediction models were used in this case because direct correlation between the site index and stand age may also result from the irregularity in localization of stands of varying ages on different site conditions, which is commonly observed (Nothdurft et al. 2012). It is particularly likely in mountainous areas, where stands at the highest altitudes under poorer site conditions are frequently older than stands at lower altitudes in richer sites. This irregularity results from the unequal accessibility to stands located at different altitudes and possibly from differences in the rotation age.

Most authors agree that observed age trend in site index estimates are the result of changing site conditions (Nothdurft et al. 2012, Pretzsch et al. 2012, 2014, Waring et al. 2014, Yue et al. 2014). However, in this paper more localized site index models developed for the Carpathians did not revealed correlations with the age of stands. Likely, this is caused by the local model built using data from trees growing under environmental changes. Moreover, a large component of the stem data used to develop the site index model comes from relatively young (60-70 years old) stands (Socha 2011). Thus, most trees were grown under the ameliorating effect of nitrogen deposition, increased temperature and $\mathrm{CO}_{2}$ concentration, and this may result in marked changes of site conditions as compared with the early 1950 s (Yue et al. 2014). Likewise, in lowland Scots pine stands in southern Poland (Socha \& Orzel 2011), site indexes calculated using site index models developed for Poland (Bruchwald et al.
2000) and Schwappach's (1943) yield tables indicated strong correlation between site index and the age of stands. However, after the use of site index model developed for local site conditions, substantial overestimation of site indexes for young stands disappeared (Socha \& Orzel 2011).

Strong correlation between site index and age of stands was apparent only in the case of site index model $S I_{B}$. We assume that the most probable cause of this is that this model was developed for the whole population of Norway spruce in Poland, including both for mountain and lowland sites. It could be expected that in mountain areas trees in young stands initially grow relatively faster than in older stands. Therefore, the use of site index models appropriate for lower elevations applied to high mountain forests may result in an age trend. Comparably different growth trajectories for high- and low-elevation stands were observed between subalpine fir, Engelmann spruce, lodgepole pine and black spruce in British Columbia (Klinkal et al. 1996, Chen \& Klinka 2000, Nigh et al. 2002). Evidence of different growth in mountain Norway spruce stands was also observed in Norway by Bøhler \& Bernt-Håvar (2011).

The most problematic issue with the proposed validation procedure is the difficult separation of the effect of change in site conditions from the effect of using inappropriate site index models on observed age trends in site indexes. However, regardless of the source of the site index age trends, the correlation between residuals of site index prediction models and the age of stands indicates inappropriate site index predictions, which makes the proposed approach useful in both cases. Moreover, both in the case of changing site productivity and inappropriate site index model, 
the usefulness of site index predictions is questionable.

Climate-based site index models may also represent an improved alternative, which take into account changes in site parameters such as temperature, precipitation, drought length, etc. (Bravo-Oviedo et al. 2008, Monserud et al. 2008). However, both traditional site index models describing site index as the function of stand age and height, and site index models including climatic parameters as additional independent variables in the case of changing site conditions, gives the assessment of the site index dependent on the age of the stand.

Most of the recently published papers on forest productivity demonstrate the high probability of further changes in site conditions around the world (Coops et al. 2007, 2010, Albert \& Schmidt 2010, Nothdurft et al. 2012). Therefore, one of the most important aspect for forest management is to attain a reliable evaluation of site index models appropriateness and its correction to local growth conditions.

\section{Conclusions}

Age trends may result from inappropriateness of site index models, often driven by: (a) local differences in top height trajectories resulting from specific site conditions, forest management practice or genetic variability; (b) inappropriate model or methods used in the development of the site index model; and (c) changes in site conditions. Relationship between the residuals of site index prediction models describing site index as a function of environmental factors and age of the stands may be used for the validation and correction of site index models in forest inventory. The existence of a correlation between residuals of site index prediction models and the age of stands implies the occurrence of systematic errors in site index determination. Such model inadequacy results in the under-/overestimation of the height of the stand in base ages. The regression model describing the relationship between the residuals of site index prediction model and the age of the stand may be used to detect the age trend in site index model, and to make it more suitable to local site conditions.

\section{Acknowledgments}

This study was financially supported by the Polish National Science Center, Grant NN-309-066939. JS acknowledges the support by the University of British Columbia (Vancouver, BC, Canada) and the University of Agriculture in Krakow (Poland).

\section{References}

Adams JP, Matney TG, Land SB, Belli KL, Duzan HW (2006). Incorporating genetic parameters into a loblolly pine growth-and-yield model. Canadian Journal of Forest Research 36: 19591967. - doi: 10.1139/x06-087

Aertsen W, Kint V, Van Orshoven J, Ozkan K,
Muys B (2010). Comparison and ranking of different modelling techniques for prediction of site index in Mediterranean mountain forests. Ecological Modelling 221: 1119-1130. - doi: 10.1016 /j.ecolmodel.2010.01.007

Albert M, Schmidt M (2010). Climate-sensitive modelling of site-productivity relationships for Norway spruce (Picea abies (L.) Karst.) and common beech (Fagus sylvatica L.). Forest Ecology and Management 259: 739-749. - doi: 10.1016/j.foreco.2009.04.039

Alvarez-González JG, Ruiz-González AD, Rodríguez-Soalleiro R, Barrio-Anta M (2005). Ecorregional site index models for Pinus pinaster in Galicia (northwestern Spain). Annals of Forest Science 62: 115-127. - doi: 10.1051/forest:2005003 Bøhler F, Bernt-Håvar $\varnothing$ (2011). Estimation of site-index in old, semi-natural stands of Norway spruce at high altitude. In: Proceedings of the Conference "Forest Management and Silviculture in the North - Balancing Future Needs". Stjørdal (Norway) 6-8 Sep 2011, Book of Abstracts. Rapport Fra Skog Og Landskap, Norway, pp. 53. [online] URL: http://www.skogogland skap.no/filearchive/estimantion_of_site_index_ in_old_semi_natural_stands.pdf

Bontemps JD, Bouriaud O (2013). Predictive approaches to forest site productivity: recent trends, challenges and future perspectives. Forestry 87: 109-128. - doi: 10.1093/forestry/cpt034 Bravo-Oviedo A, Tomé M, Bravo F, Montero G, Del Río M (2008). Dominant height growth equations including site attributes in the generalized algebraic difference approach. Canadian Journal of Forest Research 38: 2348-2358. - doi: 10.1139/X08-077

Bravo-Oviedo A, Gallardo-Andrés C, Del Río M, Montero G (2010). Regional changes of Pinus pinaster site index in Spain using a climate-based dominant height model. Canadian Journal of Forest Research 40: 2036-2048. - doi: 10.1139/ X10-143

Bruchwald A, Dudek A, Michalak K, Rymer-Dudzinska T, Wróblewski L, Zasada M (1999). Model wzrostu dla drzewostanów swierkowych [A growth model for Norway spruce stands]. Sylwan 143 (1): 19-31. [in Polish]

Bruchwald A, Michalak K, Wróblewski L, Zasada M (2000). Wzrost wysokosci sosny w róznych regionach Polski [Height growth of Scots pine in various regions of Poland]. In: "Przestrzenne zróznicowanie wzrostu sosny" [Spatial variation in Scots pine growth] (Bruchwald A ed). Fundacja Rozwój SGGW, Warszawa, Poland, pp. 77-83. [in Polish]

Buford MA, Burkhart HE (1987). Genetic improvement effects on growth and yield of Loblolly pine plantations. Forest Science 33: 707-724. [online] URL: http://www.ingentaconnect.com/ content/saf/fs/1987/00000033/00000003/artoo 011

Burkhart HE, Tomé M (2012). Modeling forest trees and stands. Springer-Verlag, Dordrecht, The Netherlands, pp. 471. - doi: 10.1007/978-90481-3170-9

Chen HYH, Klinka K (2000). Height growth models for high-elevation subalpine fir, Engelmann spruce, and Lodgepole pine in British Columbia. Western Journal of Applied Forestry 15: 62-69. [online] URL: http://www.ingentaconnect.com/ content/saf/wjaf/2000/00000015/00000002/art
00005

Cieszewski CJ (2001). Three methods of deriving advanced dynamic site equations demonstrated on inland Douglas-fir site curves. Canadian Journal of Forest Research 31: 165-173. - doi: 10.1139/xo0-132

Cieszewski CJ, Strub M (2007). Parameter estimation of base-age invariant site index models: which data structure to use? - A discussion. Forest Science 53: 552-555. [online] URL: http:// www.ingentaconnect.com/content/saf/fs/2007/ $00000053 / 00000005 /$ arto0002

Coops NC, Coggins SB, Kurz W (2007). Mapping the environmental limitations to growth of coastal Douglas-fir stands on Vancouver Island, British Columbia. Tree Physiology 27: 805-815. doi: 10.1093/treephys/27.6.805

Coops NC, Hember R, Waring RH (2010). Assessing the impact of current and projected climates on Douglas-fir productivity in British Columbia, Canada, using a process-based model (3PG). Canadian Journal of Forest Research 40: 511-524. - doi: 10.1139/Xo9-201

Elfving B, Tegnhammar L (1996). Trends of tree growth in Swedish forests 1953-1992: an analysis based on sample trees from the national forest inventory. Scandinavian Journal of Forest Research 11: 26-37. - doi: 10.1080/028275896093 82909

Fries A, Lindgren D, Ying CC, Ruotsalainen S, Lindgren K, Elfving B, Karlmats U (2000). The effect of temperature on site index in western Canada and Scandinavia estimated from IUFRO Pinus contorta provenance experiments. Canadian Journal of Forest Research 30: 921-929. doi: 10.1139/x00-029

García O (2010). Dynamical implications of the variability representation in site-index modelling. European Journal of Forest Research 130: 671-675. - doi: 10.1007/s10342-010-0458-0

Hasenauer H, Nemani RR, Schadauer K, Running SW (1999). Forest growth response to changing climate between 1961 and 1990 in Austria. Forest Ecology and Management 122: 209-219. doi: 10.1016/S0378-1127(99)00010-9

Hastie TJ, Tibshirani RJ (1990). Generalized additive models. CRC Press, Boca Raton, FL, USA, pp. 352. [online] URL: http://books.google.com/ books?id=qa29r1Ze1coC

Johansson T (1995). Site index curves for Norway spruce plantations on farmland with different soil types. Studia Forestalia Suecica 198: 119. [online] URL: http://pub.epsilon.slu.se/3658/ Kiviste A (1999). Site index change in the 1950s1990 according to Estonian forest inventory data. In: Proceedings of the International Seminar "Causes and Consequences of Accelerating Tree Growth in Europe" (Karjalainen T, Spiecker H, Laroussinie O ed). Nancy (France) 14-16 May 1998. EFI Proceedings no. 27, Joensuu, Finland, pp. 87-100. [online] URL: http://www.efi. int/files/attachments/publications/proc27_net.p df\#page $=87$

Klinkal K, Carter RE, Chert HYH (1996). Height growth-elevation relationships in subalpine forests of interior British Columbia. The Forestry Chronicle 72: 193-198. - doi: 10.5558/tfc72193-2 Monserud RA, Yang Y, Huang S, Tchebakova N (2008). Potential change in lodgepole pine site index and distribution under climatic change in Alberta. Canadian Journal of Forest Research 
38: 343-352. - doi: 10.1139/X07-166

Monserud RA (1984). Height growth and site index curves for inland Douglas-fir based on stem analysis data and forest habitat type. Forest Science 30: 943-965. [online] URL: http:// www.ingentaconnect.com/content/saf/fs/1984/ 00000030/00000004/art00015

Monserud RA, Rehfeldt GE (1990). Genetic and environmental components of variation of site index in Inland Douglas-fir. Forest Science 36: 19. [online] URL: http://www.ingentaconnect. com/content/saf/fs/1990/00000036/00000001/ arto0002

Nigh GD, Krestov PV, Klinka K (2002). Height growth of black spruce in British Columbia. The Forestry Chronicle 78: 306-313. - doi: 10.5558/tfc 78306-2

Nothdurft A, Wolf T, Ringeler A, Böhner J, Saborowski J (2012). Spatio-temporal prediction of site index based on forest inventories and climate change scenarios. Forest Ecology and Management 279: 97-111. - doi: 10.1016/j.foreco. 2012.05.018

Pretzsch H, Biber P, Schütze G, Uhl E, Rötzer T (2014). Forest stand growth dynamics in Central Europe have accelerated since 1870. Nature Communications 5: 4967. - doi: 10.1038/ncomm 55967

Pretzsch H, Dieler J, Seifert T, Rötzer T (2012). Climate effects on productivity and resourceuse efficiency of Norway spruce (Picea abies [L.] Karst.) and European beech (Fagus sylvati$\mathrm{ca}[\mathrm{L}]$.$) in stands with different spatial mixing$ patterns. Trees 26: 1343-1360. - doi: 10.1007/soo 468-012-0710-y

Pretzsch H, Grote R, Reineking B, Rötzer T, Seifert $S$ (2008). Models for forest ecosystem management: a European perspective. Annals of Botany 101: 1065-1087. - doi: 10.1093/aob/mcm 246

Schadauer K (1999). Site index and site characte- ristics of Norway spruce according to data of the Austrian Forest Inventory. Report 171, Mitteilungen der Forstlichen Bundesversuchsantalt, Wien, Austria, pp. 38.

Schwappach A (1943). Ertragstafeln der wichtigeren Holzarten [Yield tables for the most important forest tree species]. Druckerei Merkur, Prague, Czech Republic, pp. 49-55.

Sharma RP, Brunner A, Eid T (2012). Site index prediction from site and climate variables for Norway spruce and Scots pine in Norway. Scandinavian Journal of Forest Research 27: 619636. - doi: 10.1080/02827581.2012.685749

Sharma RP, Brunner A, Eid T, Oyen BH (2011). Modelling dominant height growth from national forest inventory individual tree data with short time series and large age errors. Forest Ecology and Management 262: 2162-2175. - doi: 10.1016/j.foreco.2011.07.037

Skovsgaard JP, Vanclay JK (2008). Forest site productivity: a review of the evolution of dendrometric concepts for even-aged stands. Forestry 81: 13-31. - doi: 10.1093/forestry/cpmo41

Skovsgaard JP, Vanclay JK (2013). Forest site productivity: a review of spatial and temporal variability in natural site conditions. Forestry 86: 305-315. - doi: 10.1093/forestry/cpt010 Socha J (2008). Effect of topography and geology on the site index of Picea abies in the West Carpathian, Poland. Scandinavian Journal of Forest Research 23: 203-213. - doi: 10.1080/028275 80802037901

Socha J (2011). Site index curves for Norway spruce on mountain habitats. Sylwan 155: 816826.

Socha J, Orzel S (2011). Dynamiczne krzywe bonitacyjne dla drzewostanów sosnowych Puszczy Niepolomickiej [Dynamic site index curves for Scots pine stands in Niepolomice Primeval Forest]. Sylwan 155: 301-312. [in Polish]

Solberg S, Dobbertin M, Reinds GJ, Lange H, An- dreassen K, Fernandez PG, Hildingsson A, De Vries W (2009). Analyses of the impact of changes in atmospheric deposition and climate on forest growth in European monitoring plots: a stand growth approach. Forest Ecology and Management 258: 1735-1750. - doi: 10.1016/j.for eco.2008.09.057

Spiecker H, Mielikäinen K, Kohl M, Skovsgaard J (1996). Growth trends in European forests. Springer-Verlag, Berlin, Heidelberg, New York, pp. 41-88.

Splechtna BE (2001). Height growth and site index models for Pacific silver fir in southwestern British Columbia. Journal of Ecosystem Management 1: 1-14.

Subedi N, Sharma M, Parton J (2009). An evaluation of site index models for young Black spruce and Jack pine plantations in a changing climate. Climate Change Research Report, Ministry of Natural Resources, Ontario, Canada, pp. 15. [online] URL: http://www.cabdirect.org/ab stracts/20103313288.html

Tegnhammar L (1992). On the estimation of site index for Norway spruce. Report 53, Department of Forest Survey, Swedish University of Agricultural Sciences, Uppsala, Sweden, pp. 259.

Waring R, Coops N, Mathys A, Hilker T, Latta C (2014). Process-based modeling to assess the effects of recent climatic variation on site productivity and forest function across Western North America. Forests 5: 518-534. - doi: 10.339 o/f5030518

Yue C, Mäkinen H, Klädtke J, Kohnle U (2014). An approach to assessing site index changes of Norway spruce based on spatially and temporally disjunct measurement series. Forest Ecology and Management 323: 10-19. - doi: 10.1016/j. foreco.2014.03.031 